\title{
PERFORMANCE EVALUATION OF THE CONTEMPORARY SHIPBUILDING INDUSTRIES IN BANGLADESH
}

\section{N. M. Golam Zakaria*, K. Shahriar Iqbal and K. Akhter Hossain ${ }^{* *}$}

Department of Naval Architecture and Marine Engineering, Bangladesh University of Engineering and Technology, Dhaka1000, Bangladesh.*e-mail:gzakaria@name.buet.ac.bd, ${ }^{* *}$ Ph. D Student

\begin{abstract}
:
In this paper, an effort has been made to evaluate the present shipbuilding industries in Bangladesh. To do this, at first an overall picture of this industries have been depicted by identifying the actual shipbuilding practice in both public and private sector. Relevant data have been explored through extensive review of literature, field visits, interacting with shipyard and ship owners, shipyard managers and Government regulatory and monitoring bodies using structured, unstructured and open ended questionnaires. Existing and upcoming yards have been identified and yards have been categorized by describing the shipyard in terms of modern shipbuilding requirements. The labor cost, labor hour, relative labor rate, productivity etc. have been quantified and compared with other nations. An investigation of cost breakdown of a sample exportable quality ship has been assessed to find out percentage of local components of total cost structure. The potentiality, capability and problems of the shipbuilding sector of Bangladesh have been identified \& some recommendations have been made in line with this study.
\end{abstract}

Keywords: Shipbuilding, Class ship, potentiality, labor cost, productivity

\section{NOMENCLATURE:}

$\begin{array}{ll}\text { ABS } & \text { American Bureau of Shipping } \\ \text { BV } & \text { Bureau Veritas } \\ \text { CPA } & \text { Chittagong Port Authority } \\ \text { CGT } & \text { Compensated Gross Tonnage } \\ \text { DNV } & \text { Det Norske Veritas } \\ \text { DWT } & \text { Deadweight of Ship in Tons } \\ \text { GT } & \text { Gross Tonnage } \\ \text { L } & \text { Length of Ship } \\ \text { LRS } & \text { Lloyds Register of Shipping } \\ \text { NK } & \text { Nippon Kaiji Kyokai }\end{array}$

\section{Introduction}

Bangladesh is a maritime nation with 1,66,000 sq. $\mathrm{km}$ area of sea, abundance with living and non-living resources (Alam, 2004). There are more than 200 rivers all around the country, with a total length of about $22,155 \mathrm{~km}$, which occupy about $11 \%$ of total area of the country. Here rivers and water transports play a vital role for economical and commercial activities in Bangladesh. Major export and import of Bangladesh (about $85 \%$ ) is also traveled by sea (CPA, 2007). At present more than 5,000 inland/coastal ships have been plying all over the country, which carry more than $90 \%$ of total oil product, $70 \%$ of cargo and $35 \%$ of passengers. More than 1,00,000 skilled workers and 150,000 semi-skilled workers are employed in this labor-intensive industry (Hossain and Zakaria, 2008). All inland ships are constructed and repaired in local shipyards. Bangladesh harbours the second largest ship breaking industries in the world. They are the prime source of raw material including plate, frame, stiffener, longitudinal, pipe, old engine/generator, and even auxiliary machinery, for most of the local private shipbuilding yards. Those are used as raw material in manufacturing and repairing inland shipping fleet.

Recently Bangladesh has successfully exported her first ocean going ship to Denmark, which was costing US\$ 7 million. Ananda Shipyard and Slipway Ltd, the leading private owned shipyard, got orders from Germany, Denmark and Mozambique to build more than a dozen ships with the value costing of US\$300 million. Few 1813-8235 (Print), 2070-8998 (Online) @ 2010 ANAME Publication. All rights reserved. $\quad$ Received on: July 2010 
more quality ship builders like Western Marine and High Speed Shipbuilding and Engineering works have also got orders to build dozens of ships from Germany, Netherlands, Japan, Denmark and Finland costing approximately US\$ 400 million(Hossain and Zakaria,2008).

On the other hand, as per recent statistics and world shipbuilding trend, the sea borne cargo growth was increasing 6-8\% per year and demand of new shipbuilding was increasing at the rate of $3-4 \%$ per year (Khan,2008). But the existing ship building industries are not in a position to handle this additional pressure. At the same time traditional ship building nations are burdened and as the rate of demand is increasing day by day, they have become selective in building new ships. They are not interested to build small ships of 25,000 DWT or less. So the ship owners, who are interested to build small ships of less than 25,000 DWT had to look for alternative markets. This is the reason that is allowing other nations like Bangladesh, Vietnam, Indonesia, Pakistan and India to break through the ship building industry. It is expected that this increasing rate of ship building trend will continue another era, although recession has bit slowed down the scenario.

Considering the world market and internal market, it is assumed that Bangladesh has a bright future to elevate herself as a shipbuilding nation in the world market and surely that factor should encourage more Bangladeshi entrepreneurs to come forward in this business. But shipbuilding, as a capital-intensive industry involves huge funding and also very long term investment (Stopford, 1988). That is why entrepreneurs must look into the actual picture of this industry before entering business. Unfortunately systematic data related to this industry is very rare (Fisher et al., 2008). Previously, a study had been done on prospects of shipbuilding in Bangladesh (Talukdar, 2008) covering very short span.

This paper tries to delineate the present status of the shipbuilding industry in both public and private sector. Extensive data such as details of existing and proposed shipyard, details of shipyard facilities, details of vessel built in, details of vessel exported to or order from abroad, existing \& possible ship buyers, name of the service and components of some sample ships as their suppliers, details of facilities of services/components suppliers for shipbuilding in Bangladesh, list of various types of labor required for shipbuilding \& their costs, breakup of cost \& benefit of money used in shipbuilding (Bank interest, bank guarantee, L/C margin, taxes etc. for export of local delivery) etc have been collected by means of field visit in order to identify real picture of this present shipbuilding industry, their potentiality, capability, strength and weakness. A detailed case study has been done to quantify labor hour, productivity, financial problems of the export oriented ship industries. Finally some recommendations have been made for sustainable development of this shipbuilding industry which will ultimately fulfill the objective of solving unemployment problems, boosting up foreign currency and achieving substantial economic growth of Bangladesh in the long run.

\section{Methodology used for data collection}

The following general methodology has been adopted for data collection:

i) Data were collected through extensive review of literature, field visits, survey, consultations and meetings with Government Authorities, Shipbuilding Associations, existing and upcoming shipyards and its related stakeholders.

ii) Private and public shipyards around the country were visited to collect primary data (Churchill, 1995) and information about the local shipbuilding practice through interacting with structured, unstructured and open ended questionnaires.

iii) Secondary information about shipbuilding tradition and potentiality of Bangladesh and other nation of the world were collected from both external and internal means.

iv) Shipbuilding process (such as ship design, steel treatment, plate and section preparation, welding quality, steel work, fabrication, outfitting work, hull erection and launching) was observed to assess the standard of work.

v) Primary and Secondary data about labor, labor hour and labor cost were collected to assess the labor productivity of local shipbuilding industries and to evaluate the standard of local shipyards and comparing them with other shipbuilding nations.

vi) Professional participations were conducted through Information, Questionnaire and Interviews. The organizational set up, working environment, management practices, performance and future vision of local shipyards were compared with other shipbuilding nations. 
vii) Information on different aspects related to shipbuilding industries from the stakeholders, different government supporting organizations, educational institutions including various published sources as needed were collected.

\section{Shipbuilding Industry of Bangladesh at a Glance}

\subsection{Identification of existing shipyards}

There are hundreds shipyards and workshops in Bangladesh of which 124 have been reported to be registered with the Department of Shipping (shipyard statistics, 2009). Out of these shipyards, approximately $70 \%$ are located in and around Dhaka and Narayangong along the side of the river bank of Buriganga, Shitalakha and Meghna. About 20\% shipyards of Chittagong division are located along the side of Karnapuli river and 6\% are located along the bank of Poshur river of Khulna division and remaining 4\% are located in Barishal division. The locations of the shipyards are shown in the map of Bangladesh in Fig.1. Almost all inland/coastal/bay crossing ships are constructed and repaired locally in these local shipyards.

\subsection{Categorization of shipbuilding yards}

The data collection shows that most of the yards in Bangladesh have indigenous method of construction and are not equipped with the man, machineries and equipment required to build standard ships. These yards are mainly engaged in building and repairing of inland and coastal vessels, up to 3,500 DWT. Only a few of these firms specially Ananda Shipyard and Slipways Limited (ASSL, 2008), Dhaka and Western Marine Shipyards Limited (WMSL, 2008), Chittagong have attained the capability to manufacture ships of 10,000 DWT. If the shipyards are considered on the basis of modern shipbuilding requirement, the shipyards of Bangladesh (Total 67) can be categorized into 4 classes which are shown in Fig.2.

a) Class A-Shipyard which are ready for construction of ships (Small \& Medium Category) of international standard.

b) Class B-Shipyards with some renovation \& expansion program will be ready for construction of ships (Small \& Medium Category) of international standard.

c) Class C-Proposed shipyards which are coming in production of ships (Small \& Medium Category) of international standard very soon.

d) Class D-Remaining shipyards which can make inland vessels under local regulatory standard.

\subsection{Type and Sizes of Ships being built in Bangladesh}

A number of diversified types of vessels are built in various Bangladeshi shipyards around the country, such as: multipurpose vessel, fast patrol boat, container vessel, cargo vessel, tanker, dredging barge, ro-ro ferry, passenger vessel, landing craft, tourist ship, tug, supply barge, deck loading barge, pleasure craft/yatch, crane boat, speed boat, deep sea trawler, self propelled barge, inspection vessel, cargo coaster, troops carrying vessel, double decker passenger vessel, hydrographic survey boat, pilot boat, hospital ship, water taxi, pontoon etc.

A considerable number of classed vessels have been built in Bangladesh so far. Among them 11 were classed by ABS, 5 by DNV, 3 by LRS and one vessel each by NK and BV.

\subsection{Type and Sizes of Ships being built in Bangladesh}

A number of diversified types of vessels are built in various Bangladeshi shipyards around the country, such as: multipurpose vessel, fast patrol boat, container vessel, cargo vessel, tanker, dredging barge, ro-ro ferry, passenger vessel, landing craft, tourist ship, tug, supply barge, deck loading barge, pleasure craft/yatch, crane boat, speed boat, deep sea trawler, self propelled barge, inspection vessel, cargo coaster, troops carrying vessel, double decker passenger vessel, hydrographic survey boat, pilot boat, hospital ship, water taxi, pontoon etc.

A considerable number of classed vessels have been built in Bangladesh so far. Among them 11 were classed by ABS, 5 by DNV, 3 by LRS and one vessel each by NK and BV. 
N. M. G. Zakaria*, K. S. Iqbal and K. A. Hossain / Journal of Naval Architecture and Marine Engineering 7(2010) 73-82

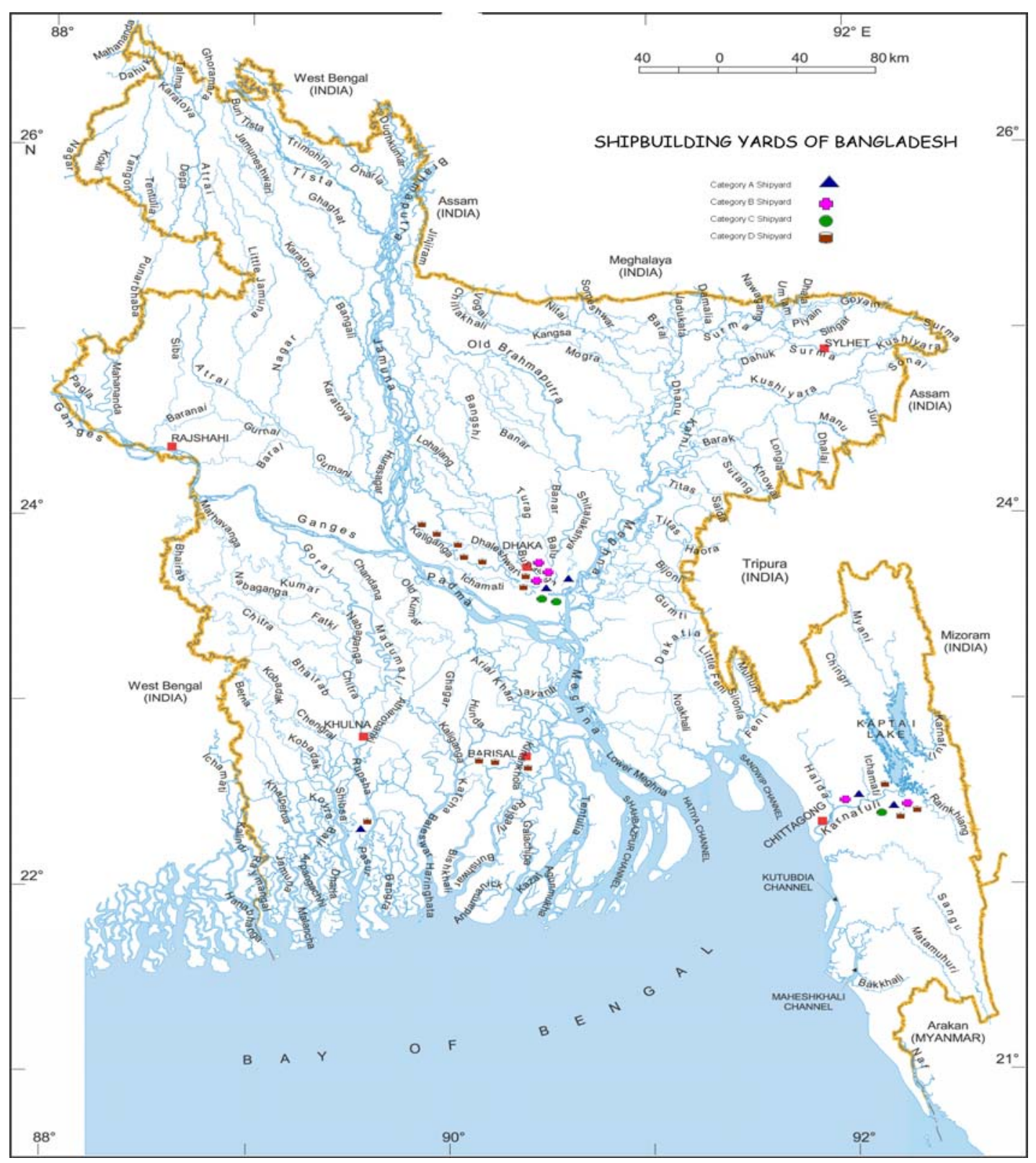

Fig.1: The location of shipyards in Bangladesh.

\subsection{Type and Sizes of Ships that can be built in the short, medium and long run}

On the capability of the technological compatibility of shipbuilding, past \& present trend, ability of the existing shipyards of Bangladesh and the interest of new comers in shipbuilding, it is anticipated that Bangladesh can build various types of ships (small \& medium category) for both inland and sea going. The present facilities will limit the size of the vessel up to 10,000 DWT, but if expansions programme of various shipyard are taken in consideration, Bangladesh will be able to build up to 50,000 DWT vessels in near future. 


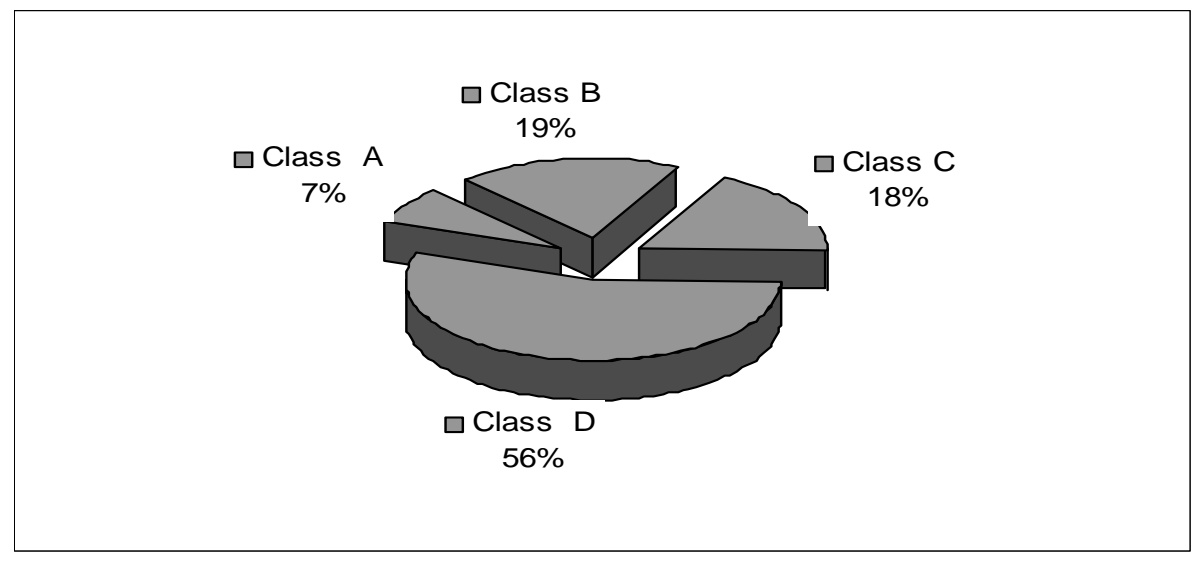

Fig.2: Categorization of shipyard in Bangladesh shown in the Pie-Chart.

\section{Factors Influencing Shipbuilding in Bangladesh}

\subsection{Global trend of shipbuilding industry}

In the past, shipbuilding industry of the East enjoyed superiority and made the region leader of civilization. After world war II shipbuilding becomes a European Industry in which Britain took the lead. This is followed by Japan (1960s to 1980s). Then South Korea took the lead. Thus the world shipbuilding market is moving east and presently Japan and South Korea have nearly equal shares of 70 percent of that market. Now, the most rapid growth in market share observed and planned is in China. But, the countries where labor costs are going up are shifting their role from small to medium and large ships. The other emerging forces are Vietnam and India. In fact, emergence of Vietnam is largely a result of efforts by European countries to relocate their shipbuilding industry to low labor cost countries. India is another rising giant in shipbuilding industry where private entrepreneurs started establishing shipyards with government support and by now the country has come to a good position in the world's shipbuilding countries and receiving orders of hundreds of millions of dollars.

Thus, shipbuilding has shifted from Europe to Japan to Korea and these days are shifting to China and Vietnam and India and now in Bangladesh and the single most driving force behind this phenomenon is lower labor cost and overhead.

\subsection{Comparison of labor cost of Bangladesh with other countries}

Cost of labour is about 20-30 percent of the cost of shipbuilding (Shenoi, 2007). Workers in US shipyards receive about US\$ 18 per hour, whereas the hourly wage is about US\$ 5.00 in some Chinese shipyards; US\$ 8 in South Korean yards, and US\$ 16 in Italian yards. Only Japan’s hourly wage of US\$ 25 exceeds U.S. labor costs. Existing average labour wage of Bangladesh which has been collected through field data is shown in Table 2.

4.3 Many of the shipyards in neighboring counties like India and Vietnam are fully occupied with medium and large ship orders. Bangladesh has still got rooms for building small and medium categories ships for international market.

\section{Performance Evaluation of Bangladeshi Shipyards}

To assess the performance of shipbuilding industries, one popular method is to collect and compare relevant data of man-hour for steel works of shipyard. Data for man-hour and rate of payment varies for inland ship and class vessel and these different hourly rates are shown in Table 2. On the other hand, since the experience of successfully completion of class vessel is not many, so we have studied the detailed case study for the first 2850 DWT exported ship which was exported to Denmark.

Empirical equation used for estimating steel work man-hour (Lamb 2002) for merchant ships is as follows:

Performance evaluation of the contemporary shipbuilding industries in Bangladesh 
$\mathrm{MH}_{\mathrm{s}}=\mathrm{CX}\left(\mathrm{W}_{\mathrm{s}}^{2 / 3} \mathrm{~L}^{2 / 3}\right) / \mathrm{C}_{\mathrm{B}}$

Where, $\mathrm{MH}_{\mathrm{s}}$ is the man-hour for steel work

$\mathrm{C}$ is the coefficient depend on the shipyard condition

$\mathrm{W}_{\mathrm{S}}$ is the net steel weight in tonnes,

$\mathrm{L}$ is the length between perpendiculars (LBP), meter,

$\mathrm{C}_{\mathrm{B}}$ is the block coefficient of ship

Table 2: Hourly Labour Charge in Bangladeshi Shipyards (including fringe benefit and manufacturer Overhead) [* 1 USD=69 Bangladeshi Taka Approx.]

\begin{tabular}{|c|c|c|c|c|}
\hline Sl No & Type of Labour & $\begin{array}{c}\text { Skill of } \\
\text { Labour }\end{array}$ & $\begin{array}{c}\text { Hourly Labour } \\
\text { Charge (in US\$*)for } \\
\text { Local ships }\end{array}$ & $\begin{array}{c}\text { Hourly Labour } \\
\text { Charge(in US\$*) } \\
\text { for Class Vessels }\end{array}$ \\
\hline 1 & Foreman & High Skilled & 0.90 & 1.20 \\
\hline 2 & Technician & High Skilled & 0.80 & 1.00 \\
\hline 3 & Specialized Welder & High Skilled & 0.75 & 1.00 \\
\hline 4 & and Gas Cutter & & 0.90 & 0.93 \\
\hline 5 & Machine Operator & High Skilled & 0.725 & 0.75 \\
\hline 6 & Gas Cutter & Skilled & 0.63 & 0.90 \\
\hline 7 & Machine Operator & Skilled & 0.69 & 1.00 \\
\hline 8 & Fitter & Skilled & 0.80 & 0.38 \\
\hline 9 & Helper & Semi Skilled & 0.38 & 0.25 \\
\hline 10 & Casual Labour & Unskilled & 0.25 & \\
\hline
\end{tabular}

The calculation of MH/CGT for steel as per empirical formula for the case of inland and ocean going ship is around 24. But actual MH/CGT (which is internationally accepted potential measure of productivity) for steel in local shipyard for export quality ship is six time higher than the international standard of MH/CGT value and for local vessel, it is 1.5 times higher than international standard. This is because, to maintain welding quality and job finishing as per international standard, the MH/ CGT for steel for export quality or class vessel produced in Bangladeshi shipyards was more. The manual welding, cutting and job fitting increase the MH/CGT in local shipyard.

The productivity for different shipbuilding nation around the world has been compared and shown in Fig.3. Fig.4 shows the comparison of relative labour rate with other countries around the world. It is estimated that, relative productivity of shipbuilding labour of Bangladesh is 11.4 and which is one of lowest among neighboring countries.

\subsection{Cost breakdown of classed shipbuilding and local shipbuilding in Bangladesh}

The tentative item-wise cost breakdown of the first exported ship has been shown graphical in Fig. 5. For local shipbuilding, only propulsion plant and some machinery which are amounting about $15-20 \%$ of total cost of ship are imported from the other country and remaining portion belongs to local products. Steel plates and structural 
materials and even some machineries are collected from scrap yard/recycling yard and they are the prime source of all inland shipyard activities.

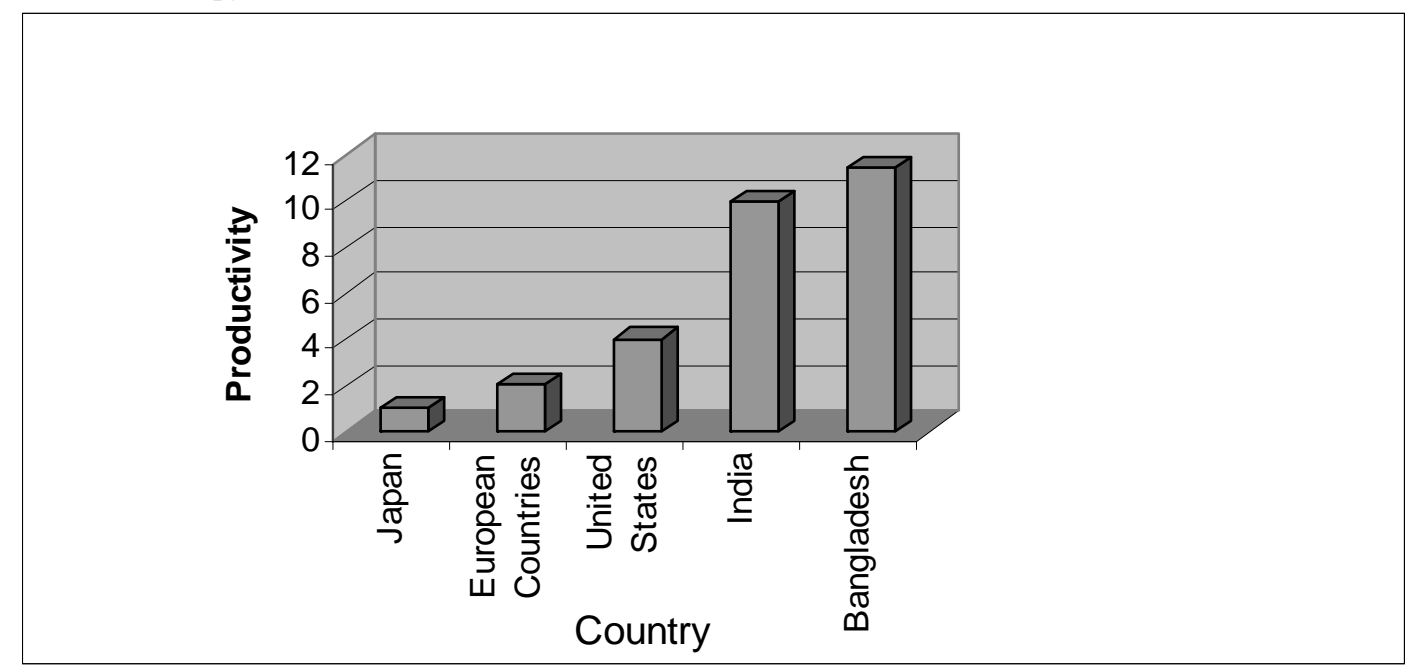

Fig.3: Shipbuilding productivity (MH/CGT) of different countries around the world

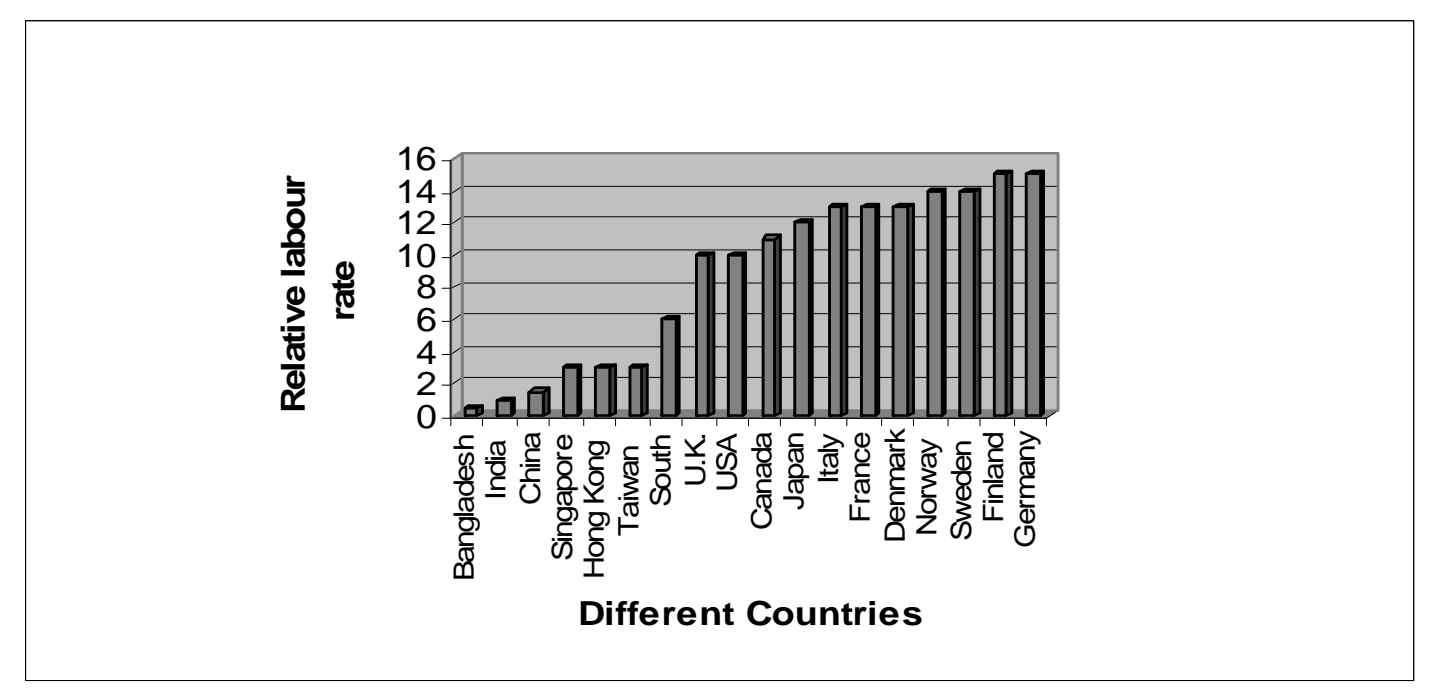

Fig. 4: Labour rate for different countries around the world

For export oriented ship as shown in Fig.5, the contribution to the local product is only $40-45 \%$ and the remaining portion has to come from exported market. Steel plates and structural materials such as angle, tee, bulb angles etc. have to be collected from outside market, although only limited portion of plates/angles (steel plate thickness up to $12 \mathrm{~mm}$ ) are available in Bangladesh.

Since shipbuilding is a capital intensive market and so financing cost which includes bank interest, bank guarantee, letter of credit (L/C) commission and other charges involving shipbuilding deserve special attention. About bank interest, Bangladeshi bank charges double digit which is unique in nature specially for shipbuilding sector with respect of other shipbuilding nations. In addition, due to double bank guarantee, L/C commission and other charges, Bangladeshi shipbuilders have to pay at least additional $15 \%$ compared to other countries as a financial cost. 


\section{Cost Breakdown of a Sample Export Quality Ship Built in Bangladesh (2850 DWT)}

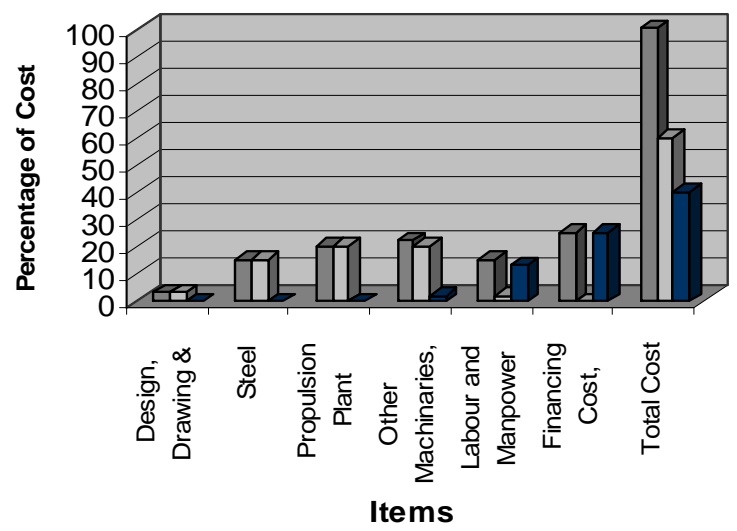

Total \%

Foreign \%

Local \%

Fig. 5: Graphical distribution of cost breakdown of exportable ship

\subsection{Status of booking for new shipbuilding in Bangladesh}

Japan, Korea and China are having the share of 38\%, 32\% and 20\% in the global shipbuilding. The demand for shipbuilding presently surpasses the capacity of the shipyards and as a results, yards in China, Korea, India, Singapore and Vietnam are booked up to 2012 with exception of some yards, which have been affected by the cancellation of orders due to economic recession (Lloyd's Register, 2008). All the factors like positive growth of the market, recent shipbuilding boom, Global trend of shifting, labor cost and status of present booking are favorable for flourishing shipbuilding industry now in Bangladesh. As a result shipbuilding capacities are rapidly expanding in Bangladesh where eighteen shipyards are now in different stages of development. Seven shipyards who are involved in building and repairing ships for inland water transportation are also developing facilities for building ocean going ships by enhancing their yard capacity to enter into export market. The order books of Bangladeshi shipyard (including DWT \& minor detail) at present are given in Table 3. Growth of vessel order in entire global market and position of Bangladesh has been shown in Fig.6.

Table 3: At present Bangladesh have the orders for following vessels from abroad (with their DWT).

\begin{tabular}{|c|c|c|c|c|}
\hline $\begin{array}{c}\text { Name of the } \\
\text { shipyard }\end{array}$ & Type of vessel & Quantity & DWT & $\begin{array}{c}\text { Owner's } \\
\text { country }\end{array}$ \\
\hline Ananda Shipyard & Multipurpose ship & 8 & 7250 & Germany \\
\hline Ananda Shipyard & Multipurpose ship & 6 & 5500 & Germany \\
\hline Ananda Shipyard & Container ship & 3 & 2900 & Denmark \\
\hline Ananda Shipyard & Multipurpose ship & 6 & 6100 & Germany \\
\hline $\begin{array}{c}\text { Western Marine } \\
\text { Shipyard Limited }\end{array}$ & Multipurpose Cargo vessel & 5 & 4100 & Denmark \\
\hline $\begin{array}{c}\text { Western Marine } \\
\text { Shipyard Limited }\end{array}$ & Multipurpose Cargo vessel & 12 & 5200 & Netherlands \\
\hline $\begin{array}{c}\text { Western Marine } \\
\text { Shipyard Limited }\end{array}$ & $\begin{array}{c}\text { Floating Reception Vessel } \\
\text { (Delivered) }\end{array}$ & 1 & 230 & Finland \\
\hline
\end{tabular}

\section{Results and Discussion}

In Bangladesh, more than one-fourth shipyards are ready or to be ready with little renovation for construction of small and medium sized vessels of international standards. Though the MH/CGT is the highest in Bangladesh, 
the lowest labour cost has kept the direct cost of ship production to a minimum level. But the high additional charges like bank interest, L/C commission etc. have put this sector into an uneven competition in the international shipbuilding market. Since more than $50 \%$ of the ship cost is related to the export market, some favorable policy like bringing the bank interest to a single digit and tax exemption on imported parts of ship taken by the Government of Bangladesh may support flourishing the shipbuilding industry in Bangladesh. These types of favorable policies will encourage more entrepreneurs to come forward in this business and thus Bangladeshi shipbuilding will continue to move ahead to compete and grab order of considerable portion for small and medium ship construction from the international shipbuilding market.

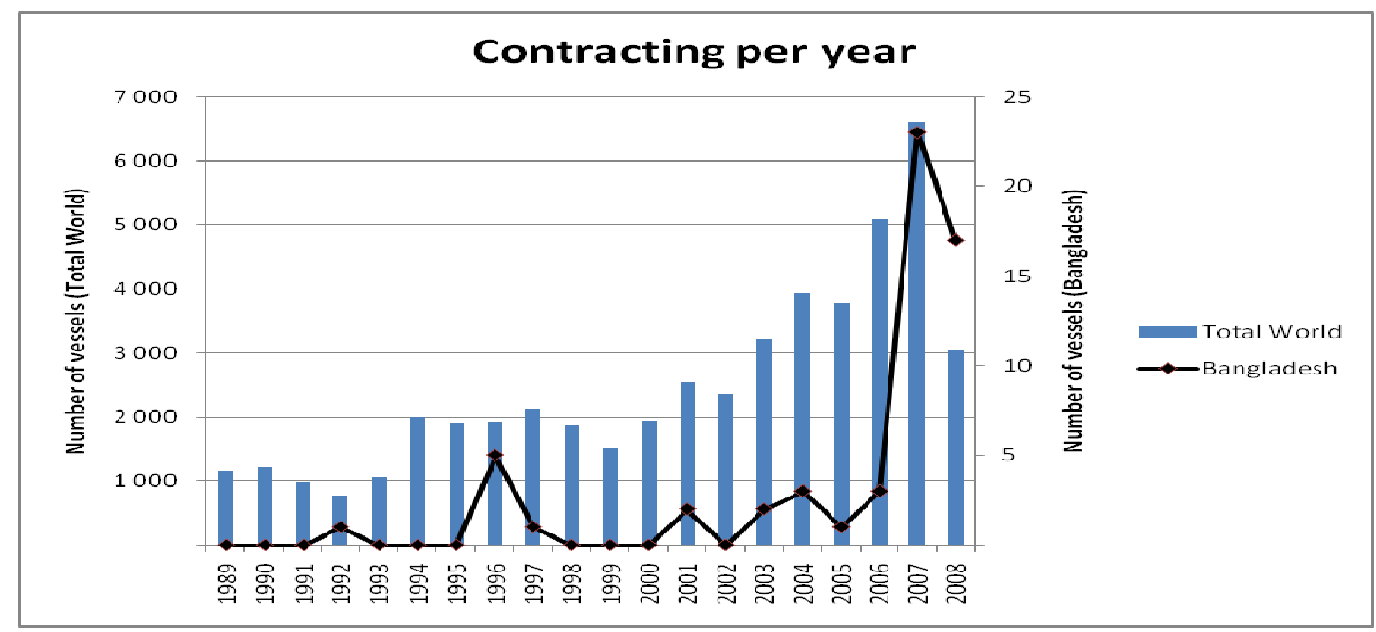

Fig.6: Vessel order (entire world market \& position of Bangladesh) (Patrik Wager,2008)

\section{Conclusions and Recommendations}

Shipbuilding industry plays an important role in assisting national defense, promoting shipping and industrial development, increasing employment and foreign currency inflow. It is therefore an attractive industry for Bangladesh. On the basis of studies of contemporary shipbuilding industries in Bangladesh, the following conclusions may be drawn:

a) Bangladeshi shipbuilding is capable of producing international standard ship of small to medium category and at present, more than $25 \%$ shipyards are ready or to be ready with little renovation for construction of small and medium sized vessels of international standards.

b) Because of long heritage of shipbuilding, Bangladesh has abundance of skilled, semi-skilled and easily trainable manpower for supporting shipbuilding industry and labor cost is the cheapest among others shipbuilding nations.

c) Productivity of Bangladeshi work force in shipbuilding is 11.4 which is lowest in the world. It is essential to upgrade the productivity through conducting training program, incorporating process enhancement, modernizing yard facilities and employing more integrated production technology, otherwise it is difficult to sustain in this competitive industry in the long run.

d) Prevailing financial sector is not conducive to flourish the capital intensive shipbuilding. Higher rate of interest on industrial and working capital loan, bank guarantee, $\mathrm{L} / \mathrm{C}$ margin \& the commission for the import L/C should be fixed at lowest possible level for $100 \%$ export oriented shipbuilding industry.

e) At present Bangladeshi class ship contain just $15-20 \%$ of local content which includes labors and some components. Using the experiences \& expertise of the small \& medium (SME) industries, it is possible to upgrade them as a supporting industry for the exporting ships. In this way, it is possible to increase domestic output significantly.

\section{References}

Alam, K.(2004): Bangladesh’s Maritime Challenges in $21^{\text {st }}$ Century, Pathak Shamabesh Book Publication Limited, Dhaka. 
N. M. G. Zakaria*, K. S. Iqbal and K. A. Hossain / Journal of Naval Architecture and Marine Engineering 7(2010) 73-82

ASSL (2008): Brochure of Ananda Shipyard and Slipways Ltd, Ananda Group, Dhaka.

WMSL (2008): Booklet of Western Marine Shipyard Ltd, WMSL, Chittagong.

Churchill, G.A. (1995): Marketing Research Methodological Foundation, Sixth edition, Harcourt Brace College Publishers, USA.

Chou, C. C. and Chang P.L.(2001): Modeling and Analysis of Labor Cost Estimation for Shipbuilding : The Case of China Shipbuilding Corporation, Vol.17, No.2, May 2001, pp 92-96.

Khan, J. U. (2008): Bangladesh Local Firm to Build 10 Ships for Japan, 20 June, www.thedailystar.net. Accessed on June 27, 2008.

Fisher, J.O. and Holbaach, I.G (2008): Cost Management in Shipbuilding, The Naval Architects, November, 2008.

Hossain, K. A. and Zakaria, N. M. G., 2008: Potentiality and Prospect of Shipbuilding Industries in Bangladesh, Journal of NOAMI, Vol.25, No.2, pp. 33-54.

Lamb, T. and Hellesoy, A. (2002): A Shipbuilding Productivity Predictor, Journal of Ship Production, Vol.18, No. 2, May 2002, pp.79-85.

LR (2008): World shipbuilding report, Lloyd's Register, (www.lrfairplay.com).

Patrik Wägar (2008): Regional Sales Direct, Ship Power, Wärtsilä Corp.

Stopford, M. (1998): Maritime Economics, Unwin Hyman Press, London.

Shenoi, R. A. (2007): Ship Production Technology, University of Southampton, UK

DOS (2009): Shipyard Statistics, Engineering Section, Department of Shipping of Bangladesh, Dhaka.

Talukdar, N.S. (2008): Prospect of Shipbuilding in Bangladesh, Undergraduate Thesis, Dept. of Naval Arch \& Marine Engg., BUET.

CPA (2007): Year Book of the Chittagong Port Authority, CPA, Chittagong. 